\title{
Obesity and asthma: co-morbidity or causal relationship?
}

\author{
A. van Huisstede, G.J. Braunstahl
}

ABSTRACT: Obesity and asthma: co-morbidity or causal relationship? A. van Huisstede, G.J. Braunstahl.

There is substantial evidence that obesity and asthma are related. "Obese asthma" may be a unique phenotype of asthma, characterized by decreased lung volumes, greater symptoms for a given degree of lung function impairment, destabilization or lack of asthma control, lack of eosinophilic inflammation and a different response to controller medication.

Whether this relationship between obesity and asthma is causal or represents co-morbidity due to other factors is unclear. In previous reviews concerning the relationship between obesity and asthma, five hypotheses were put forth. One of these hypotheses is that a low grade systemic inflammation caused by adipokines from the fat tissue causes or enhances bronchial inflammation. In animal models, there is an increasing amount of evidence for the role of adipokines derived from fat tissue in the relationship between obesity and asthma. The data are conflicting in humans.

Since obesity is a component of the metabolic syndrome and the metabolic syndrome is also a form of systemic inflammation, it is to be expected that there is a relationship between metabolic syndrome and asthma. The few data that are available show that there is no relationship between metabolic syndrome and asthma, but there is one between the metabolic syndrome and asthma-like symptoms.

Further research is needed to confirm the relationship between obesity and asthma in humans, where a rigorous approach in the diagnosis of asthma is essential. Monaldi Arch Chest Dis 2010; 73: 3, 116-123.

Keywords: Asthma, Obesity, Systemic inflammation, Metabolic Syndrome.

Correspondence: A. van Huisstede, Sint Franciscus Gasthuis, Secretariaat Maatschap Interne Geneeskunde, Kleiweg 500, 3045 PM Rotterdam,The Netherlands; e-mail:a.vanhuisstede@sfg.nl

\section{Introduction}

Obesity is currently a major health problem and is developing into a global epidemic. Obesity is classified by the Body Mass Index (BMI) (table 1) and is defined as abnormal or excessive fat accumulation which can cause health problems. The World Health Organisation's (WHO) latest projections indicate that, globally in 2005, approximately 1.6 billion adults (age 15+) were overweight, and at least 400 million adults were obese. WHO further predicts that, by 2015, approximately 2.3 billion adults will be overweight and more than 700 million will be obese [1].

Because the prevalence of both obesity and asthma have increased in the recent years, many studies have examined the possibility of a causal relationship between these two conditions [2-5]. The fact that asthma improves after weight loss with either bariatric surgery or low caloric diet

Table 1. - Classification of different BMI-classes

\begin{tabular}{ll}
\hline BMI $\left(\mathrm{kg} / \mathrm{m}^{2}\right)$ & Classification \\
$<18.5$ & Underweight \\
$18.5-25$ & Normal weight \\
$25-30$ & Overweight \\
$30-40$ & Obesity \\
$>40$ & Morbid Obesity
\end{tabular}

BMI: Body Mass Index. supports the relationship between obesity and asthma [6]. Moreover, obese patients with persistent asthma have significantly worse asthma-related quality of life [7], less asthma control [8,9], more severe disease [4, 10-12], and more asthma-related hospital admissions than asthma patients with a normal BMI.

There are multiple hypotheses that may explain the relationship between obesity and asthma. This review will discuss the different hypotheses, and will focus on the systemic inflammation, and the possible role of the metabolic syndrome.

\section{Asthma phenotype in obesity}

Recent data suggest $[13,14]$ that obese patients have a different phenotype of asthma, characterized by female predominance, late onset of asthma and high symptom expression.

Classical asthma is characterised by a Th-2 cell mediated allergic airway inflammation. The characteristics of airway inflammation in asthma (exhaled nitric oxide, eNO, and inflammatory cells in induced sputum) have been investigated in obesity. eNO can be seen as a marker of eosinophilic inflammation in the airways. De Winter et al. showed that a higher BMI was associated with a higher eNO in healthy patients [15]. On the contrary, Kazaks found no significant relationship between exhaled NO and BMI in adult asthma patients [16]. However, there was no correction for use of corticosteroids. 
Sputum eosinophilia is a hallmark of asthma. Several studies have found no - or even an inverse - relationship between the number of sputum eosinophils and BMI [17-19]. Although airway eosinophil accumulation is characteristic for asthma, little is known about the influence of obesity on eosinophil migration from bone marrow to the bronchial mucosa. Calixto [20] found, in a murine model of asthma, that diet-induced obesity enhanced eosinophil trafficking from bone marrow to the airway, but delayed their transit through the airway epithelium into the airway lumen.

If the relationship between asthma and obesity could be explained by allergic airway inflammation, then one would expect a relationship between obesity and other allergic conditions, such as allergic rhinitis or allergic conjunctivitis. Although several epidemiologic studies have reported an increased risk of atopy in the overweight and/or obese [21,22], others have demonstrated an increased risk of developing asthma in non-allergic compared to allergic adults [23-25].

In summary, there is a great deal of conflicting data concerning the signs of bronchial inflammation in obese asthmatics (eNO, sputum eosinphilia). Data suggest that asthma in obese patients is not characterized by a classic Th2 cell driven inflammation, but probably represents a different phenotype. The inflammatory pattern might be neutrophilic, instead of eosinophilic in obese patients with asthma. Allergy is probably not an important factor in the relationship between obesity and asthma.

\section{Therapeutic implications}

The main goal of asthma treatment is to achieve adequate control of the disease, as reflected by minimal symptoms and rescue bronchodilator use. Asthma has been reported to be more difficult to control in obese patients compared to individuals with a normal weight $[9,26]$. Also the improvement of exhaled nitric oxide levels with inhaled corticosteroid treatment is smaller in obese asthmatics than in lean asthmatics [27]. Is this because they do not respond to inhaled corticosteroids? This could be expected when one assumes that in obese asthmatics it is a neutrophilic instead of eosinophilic airway inflammation. In a recent study by Camargo [28], they found that, compared to subjects with normal BMI, the onset to peak $\mathrm{FEV}_{1}$ may require longer treatment exposure in the very obese.

Could it be that asthma in obese patients is more difficult to control because obese asthmatics have more complaints than lean asthmatics? Although obese asthmatics have the same perceptual responses to bronchoconstriction as lean asthmatics, it is to be expected that they have more complaints of dyspnoea due to their altered lung volumes as will be discussed later.

Weight reduction from diet and exercise has been found to improve asthma symptoms, but the most striking changes have been reported in morbidly obese asthmatics following bariatric surgery
[29-34]. However, these studies are frequently small and underpowered, and are often not designed with a primary outcome or rigorous characterization of asthma. Although there is still only a small body of evidence in favour of the beneficial effect of weight reduction in obese asthmatics, weight reduction does seem to be an important aspect of the treatment of these people.

\section{Hypotheses that may explain the relationship between obesity and asthma}

Since obese asthmatics might have a non-allergic phenotype of asthma, there must be another factor explaining the relationship between obesity and asthma. Although there are multiple hypotheses, no causal relationship between obesity and asthma has, as yet, been proven. Even though asthma may promote weight gain through increased sedentary life style and occasional use of oral corticosteroids, this does not fully explain the association of asthma and obesity in the majority of patients. In previous reviews concerning the relationship between obesity and asthma, five hypotheses were put forth (figure 1).

First, obese people consume food with less nutritional value, fewer vitamins and more fat. A high amount of fat intake is associated with asthma [35]. Also zinc- and magnesium deficiencies are associated with asthma and bronchial hyperreactivity (BHR) [36].

Secondly, obesity and asthma may share the same genetic risk factors. This was demonstrated by a large-scale study among 1384 twins, where a strong association between asthma and BMI was found [37].

Co-morbidities, which are a risk factor for asthma as well as obesity, might be the third hypothesis. Obesity, for instance, is a risk factor for gastro-oesophageal reflux disease (GERD) which, in turn, is a risk factor for asthma [38]. The same is true for Obstructive Sleep Apnoea Syndrome (OSAS); the prevalence of OSAS is higher in severe asthma patients as well as in obese patients [39]. A large-scale, questionnairebased Northern European survey showed that after adjustments for possible confounders, obesity and nocturnal GERD were found to be independent risk factors for the onset of asthma and respiratory symptoms [40].

Fourthly, obesity may alter lung function parameters. Typically, obesity causes a modest reduction in total lung capacity (TLC), and a larger reduction in functional residual capacity (FRC) (figure 2) [41]. The reasons for the reduction in TLC are not known, but they are probably due to a mechanical effect of the adipose tissue. A reduction in the downward movement of the diaphragm, due to increased abdominal mass is likely to decrease TLC by limiting the space for lung expansion on inflation [42]. Furthermore, obese people have a smaller tidal volume and an increased respiration rate with a decreased expiratory reserve volume (ERV) [43]. The $\mathrm{FEV}_{1} / \mathrm{FVC}$ ratio is usually well 


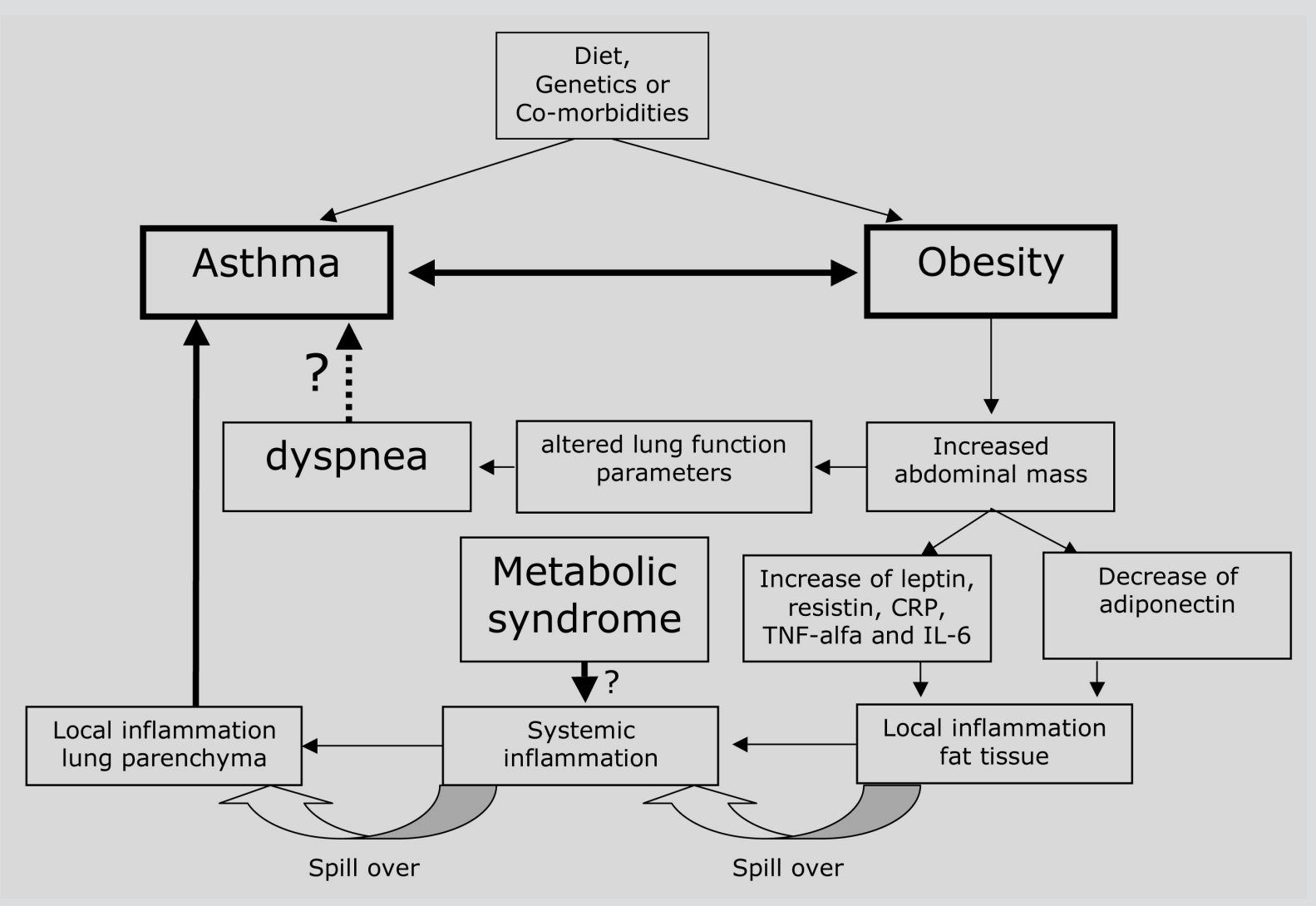

Fig. 1. - The relationship between obesity and asthma is not yet clear. Diet, genetic factors or comorbidities which give a higher risk for asthma might also give a higher risk for obesity. Obesity gives a greater abdominal mass, which causes altered lung function parameters, which cause dyspnea. Whether or not this dyspnea is asthma is questionable. The abdominal mass also causes a dysbalance in inflammatory proteins, in favour of the pro-inflammatory proteins. This may lead to a local inflammation, which causes a low grade systemic inflammation, which, in turn, causes or enhances a local inflammation of the lung parenchyma.

preserved or increased, which implies that the major effect of obesity is on lung volumes, with no direct effect on airway obstruction. Furthermore, weight loss significantly improves the FRC, TLC and ERV [44].

The decreased lung volume is associated with a decreased diameter of the peripheral airways, which leads to tidal breathing at or near closing volume [41]. Moreover, Bergeron has shown that there is a fat accumulation in the airways in obese patients with less defined cartilage ring [45]. All this can explain why obese patients often have more complaints of dyspnea than subjects with a normal BMI. Salome showed that, although obesity reduces lung volumes, it does not alter sensitivity or maximal response to methacholine in nonasthmatic subjects [46]. Recently, it was also shown that perceptual responses to methacholineinduced bronchoconstriction and lung hyperinflation were similar in obese and normal-weight asthmatics [47]. Thus, obese asthmatics may have more complaints of dyspnea, but this may not be directly related to abnormal airway sensitivity, but may reflect other physiological effects of obesity.

The fifth, and last, hypothesis suggests that systemic inflammation by means of fat-tissue derived adipokines may lead to asthma. The assumption is that inflammatory mediators from the fat tissue come into the systemic circulation, and find their way to the lung parenchyma, where they may cause or intensify airway inflammation [43].

Obesity is considered to be a state of chronic low-grade systemic inflammation, characterized by a dysbalance of pro- and anti-inflammatory proteins derived from fat tissue cells. Fat tissue was traditionally seen as an organ for storage of energy. Recently, however, it is considered to act as an endocrine organ. The fat tissue is a source of bioactive peptides, which are called adipokines [48]. In 1993, Hotamisligil et al. discovered that fat cells (adipocytes) in rodents excrete TNF- $\alpha$. TNF- $\alpha$ is a pro-inflammatory cytokine [49]. Since then, multiple inflammatory peptides have been discovered which have a relationship with obesity. Examples of adipokines are leptin, adiponectin and resistin. Also interleukin (IL)- 6 and TNF- $\alpha$ play a role. They are produced by macrophages in the fat tissue.

Leptin (from the Greek word "leptos", thin) is excreted by fat tissue and causes the feeling of saturation and increases the metabolism. Moreover, leptin influences the T-cell immunity response and stimulates the proliferation of T-helper cells, which causes increased production of pro-inflammatory cytokines [50]. There is an increased leptin production [51, 52] and a relative leptin resistance in obese patients. A comparison with insulin and insulin resistance can be made: here the primary 


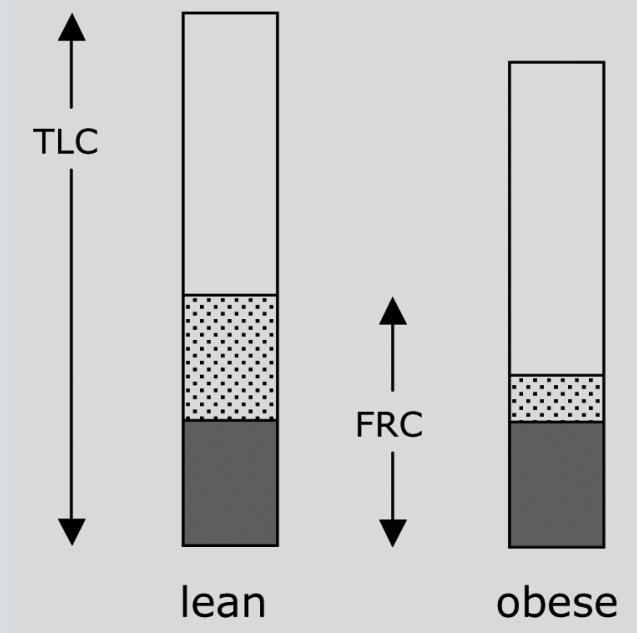

Fig. 2. - Obesity leads to alternations of lung volumes. ERV: expiratory reserve volume; FRC: functional residual capacity; RV: residual volume; TLC: total lung capacity.

reaction of the body is to increase the production of insulin so that the same physical result is achieved. The leptin concentration is not only increased in obesity, but also in asthma $[53,54]$.

Obesity is associated with necrosis of the adipocytes, causing the interstitium to be exposed to little fat drops. Macrophages will collect around this necrotizing adipocytes and become active. These macrophages will produce TNF- $\alpha$ and IL-6, which will cause a decrease in local production of adiponectin [55]. Adiponectin is an insulin-regulating hormone. It also has anti-inflammatory effects: it decreases the production of pro-inflammatory cytokines and it increases the production of IL-10 and IL-1. Plasma adiponectin levels are reversely correlated to BMI [56], but there is no clear relationship between adiponectin and asthma [57-60].

$\mathrm{Xu}$ et al. [61] have been able to show in a mice model that there is histological evidence for a significant infiltration of macrophages in the fat tissue of obese mice. Moreover, they also have shown that many inflammatory and specific macrophage genes are dramatically upregulated in the fat tissue. This suggests that macrophages in the fat tissue play an active role in obesity and macrophage-related inflammation. Weisberg et al. [62] showed that the macrophages are responsible for almost all expression of TNF- $\alpha$ and IL- 6 in the fat tissue. TNF- $\alpha$ is a potent pro-inflammatory cytokine and is involved in many processes in the human body, in particular inflammation, cell proliferation, cell differentiation, apoptosis and fat metabolism. IL-6 regulates the production of the strong pro-inflammatory protein C-reactive protein (CRP).

In summary, in animal models the influence of the different adipokines associated with obesity seem to have an effect on the airway inflammation. In humans, however, the association is not yet con- firmed. Further studies are needed to investigate whether a dysbalance in pro and anti-inflammatory cytokines in the systemic circulation may induce a change in concentration of the same cytokines in the lung tissue. This may result in an increased airway inflammation.

\section{Metabolic syndrome}

The fact that asthma improves after weight loss either with bariatric surgery or low caloric diet supports the relation between obesity and asthma. Moreover, Cottam found that obesity was manifested by a chronic inflammation (including elevation of monocytes and eosinophils), which appeared to be reversible within 6 months after bariatric surgery [63]. Also, weight loss by lowenergy diet was associated with a reduction in markers of systemic inflammation $[64,65]$. So the hypothesis that the relationship between obesity and asthma is based on a systemic inflammation seems quite plausible. The metabolic syndrome might contribute to this low-grade systemic inflammation.

Recently, the metabolic syndrome has been postulated as a new hypothesis which might explain the relationship between obesity and asthma. Obesity, and mainly central obesity, is an important component of the metabolic syndrome. The metabolic syndrome is a term to cluster type 2 diabetes mellitus, hypertension, dyslipidemia and central obesity (table 2).

Leone found an independent relationship between lung function impairment $\left(\mathrm{FEV}_{1}\right.$ or $\mathrm{FVC}<$ lower limit of normal) and metabolic syndrome in both sexes, predominantly due to abdominal obesity [66]. Lee et al. [67] found that the metabolic syndrome was associated with asthma symptoms. The evidence for the relationship between metabolic syndrome and asthma is scarce, mainly because it is a new idea. More research is needed to make a definitive conclusion.

The metabolic syndrome is a way to group different diseases. If there might be a relationship between the metabolic syndrome and asthma, there might also be a relationship between the separate compounds of the metabolic syndrome and asthma. In a cross-sectional population-based study, obesity and insulin resistance were associated with an increased risk of aeroallergen sensitization and asthma (allergic and non-allergic) [68]. Thuesen [69] found, in a recent population-based, prospective study among 1443 adults, that insuline-resistance is a stronger risk factor for asthma symptoms than obesity. Hyperglycemia itself may not be the important factor. Shore et al. have demonstrated in lean wild-type and leptin receptor-deficient, diabetic, obese mice that administration of metformin did not affect ozone-induced airway inflammation [70].

More research is needed to see whether the metabolic syndrome, or it separate components, are the "missing link" between obesity and asthma. Also here the same remarks as for the fat tissue derived adipokines can be made. If it is so that 
Table 2. - Definition of the metabolic syndrome according to NCEP-ATPIII criteria on basis of clinical characteristics. Metabolic syndrome when 3 out of 5 characteristics

\begin{tabular}{|c|c|}
\hline Risk factor & Objective \\
\hline \multicolumn{2}{|c|}{ Abdominal obesity (waist circumference) } \\
\hline - male & $>102 \mathrm{~cm}$ \\
\hline - female & $>88 \mathrm{~cm}$ \\
\hline Triglycerides & $>1,7 \mathrm{mmol} / \mathrm{l}$ or treatment for hypertriglyceraemia \\
\hline \multicolumn{2}{|l|}{ HDL-cholesterol } \\
\hline - male & $<1,03 \mathrm{mmol} / \mathrm{l}$, or treatment for low HDL-C \\
\hline - female & $<1,3 \mathrm{mmol} / 1$ or treatment for low HDL-C \\
\hline Blood pressure & $\geq 130 / \geq 85 \mathrm{mmHg}$, or treatment for hypertension \\
\hline Blood glucose (plasma) & $\geq 6,1 \mathrm{mmol} / \mathrm{l}$, or treatment for hyperglycaemia \\
\hline
\end{tabular}

the metabolic syndrome contributes to the low grade systemic inflammation, the question remains whether this low grade systemic inflammation has its local effects on the lung parenchyma. And whether this systemic inflammation causes or enhances the bronchial inflammation.

\section{Critical notes}

Many of the articles discussed in this review are epidemiologic studies among patients with asthma, where asthma is defined as either physician-diagnosed or self-reported. Very few studies performed (extensive) lung function tests to confirm the diagnosis of asthma. Often the diagnosis is based on symptoms and medication use. The question is whether these patients truly have asthma. In a retrospective study among children, a strong correlation was found between general practitioner and specialist diagnosed asthma, irrespective of BMI [71]. In an extensive study among adult patients, the diagnosis of asthma was revisited. In $31.8 \%$ of the obese, and $28.7 \%$ of the nonobese group $(p=0.46)$ the diagnosis of asthma was rejected. The percentage of misdiagnosis is the same in the obese and non-obese group, so the relationship between asthma and obesity can not be explained by the fact that there is an overdiagnosis of asthma in the obese population [72]. In a recent study Pakhale et al. [73] found a misdiagnosis of asthma in up to $30 \%$ of patients. They used a rigorous diagnostic testing algorithm to confirm the diagnosis of asthma. They found that misdiagnosis of asthma was associated with gender, a recent diagnosis, older age and increased $\mathrm{FEV}_{1}$, but not with obesity. Also, obese subjects who made urgent healthcare visits for respiratory symptoms were more likely to be misdiagnosed with asthma. It is possible that these symptoms could be the result of increased effort in breathing associated with obesity, rather than airway inflammation or airway hyperresponsiveness.

Another disadvantage of most studies is that they are based on self-reported weight. A BMI based on self-reported height and weight is not ac- curate for either children or adults [74]. The weight will be underreported, and the length overreported. There is however, an algorithm to correct for this.

Some previous studies of the association of adiposity and lung function have used only BMI as a marker of obesity, without taking body composition and fat distribution into account. The waist circumference - or even better, a MRI-based visceral fat quantification - is possibly a more accurate measure than BMI. The distribution of body fat may be an important determinant of lung function, and this may account for the more pronounced association between central adiposity and obstructive lung function in men as compared to women [75]. Steele et al. performed a study to examine the relationship among body fatness, fat distribution, and lung function, adjusted for physical activity, energy expenditure and aerobic fitness [76]. They found that obesity is inversely associated with lung function ( $\mathrm{FEV}_{1}$ and $\mathrm{FVC}$ ) in adults. Central fat distribution, however, appears to have a stronger relationship to respiratory mechanics $\left(\mathrm{FEV}_{1}\right)$ in men than in women. These associations were independent of the degree of physical activity in this cohort.

\section{Conclusion}

From the literature discussed, it can be concluded that there is a relationship between obesity and asthma. "Obese asthma" may be a unique phenotype of asthma, characterized by decreased lung volumes, greater symptoms for a given degree of lung function impairment, destabilization or lack of asthma control, lack of eosinophilic inflammation and a different response to controller medication. Therefore, the clinical evaluation of an obese patient with asthma must require a more rigorous and objective approach.

Whether this relationship is really causal or represents parallel co-morbidities is unclear. In animal models, there is an increasing amount of evidence for the role of adipokines derived from fat tissue in the relationship between obesity and asth- 
ma. This adipokines cause a low grade systemic inflammation, which might cause or enhance bronchial inflammation. The data are conflicting in humans. However, the fact that weight loss improves asthma control and normalizes the concentration of adipokines in the serum implies that there must be some role for adipokines in the relationship between obesity and asthma.

Since obesity is a component of the metabolic syndrome and the metabolic syndrome is also a form of systemic inflammation, it is to be expected that there is a relationship between metabolic syndrome and asthma. The few data that are available show that there is no relationship between metabolic syndrome and asthma, but there is one between the metabolic syndrome and asthma-like symptoms.

Further research is needed to confirm the relationship between obesity and asthma in humans, where a rigorous approach in the diagnosis of asthma and use of good control groups is essential. Intervention-based longitudinal research might find a definitive answer to the question of what the basis of the relationship between obesity and asthma could be.

Acknowledgements: We wish to thank Mrs. Reijnhart for editing the manuscript.

\section{References}

1. Organisation WH. Obesity and overweight, fact sheet No 311. 2006 [cited; Available from: http: //www.who. int/mediacentre/factsheets/fs311/en/print.html

2. James AL, Knuiman MW, et al. Changes in the prevalence of asthma in adults since 1966: the Busselton health study. Eur Respir J 2010; 35: 273-8.

3. Chen Y, Rennie D, Cormier Y, Dosman J. Atopy, obesity, and asthma in adults: the Humboldt study. $J$ Agromed 2009; 14: 222-7.

4. Taylor B, Mannino D, Brown C, Crocker D, TwumBaah N, Holguin F. Body mass index and asthma severity in the National Asthma Survey. Thorax 2008; 63: 14-20.

5. Beuther DA, Sutherland ER. Overweight, obesity, and incident asthma: a meta-analysis of prospective epidemiologic studies. Am J Respir Crit Care Med 2007; 175: 661-6.

6. Camargo CA, Jr., Weiss ST, Zhang S, Willett WC, Speizer FE. Prospective study of body mass index, weight change, and risk of adult-onset asthma in women. Arch Intern Med 1999; 159: 2582-8.

7. Lavoie KL, Bacon SL, Labrecque M, Cartier A, Ditto B. Higher BMI is associated with worse asthma control and quality of life but not asthma severity. Respir Med 2006; 100: 648-57.

8. Saint-Pierre P, Bourdin A, Chanez P, Daures JP, Godard P. Are overweight asthmatics more difficult to control? Allergy 2006; 61: 79-84.

9. Clerisme-Beaty EM, Karam S, et al. Does higher body mass index contribute to worse asthma control in an urban population? J Allergy Clin Immunol 2009; 124: 207-12.

10. Mosen DM, Schatz M, Magid DJ, Camargo CA, Jr. The relationship between obesity and asthma severity and control in adults. J Allergy Clin Immunol 2008; 122: 507-11 e6.
11. Akerman MJ, Calacanis CM, Madsen MK. Relationship between asthma severity and obesity. J Asthma 2004; 41: 521-6.

12. Varraso R, Siroux V, Maccario J, Pin I, Kauffmann F Asthma severity is associated with body mass index and early menarche in women. Am J Respir Crit Care Med 2005; 171: 334-9.

13. Haldar P, Pavord ID, Shaw DE, et al. Cluster analysis and clinical asthma phenotypes. Am J Respir Crit Care Med 2008; 178: 218-24.

14. Lugogo NL, Kraft M, Dixon AE. Does obesity produce a distinct asthma phenotype? J Appl Physiol 2010 Mar; 108: 729-34

15. De Winter-de Groot KM, Van der Ent CK, Prins I, Tersmette JM, Uiterwaal CS. Exhaled nitric oxide: the missing link between asthma and obesity? J Allergy Clin Immunol 2005; 115: 419-20.

16. Kazaks A, Uriu-Adams JY, Stern JS, Albertson TE. No significant relationship between exhaled nitric oxide and body mass index in people with asthma. $J$ Allergy Clin Immunol 2005; 116: 929-30; author reply 30.

17. Todd DC, Armstrong S, D'Silva L, Allen CJ, Hargreave FE, Parameswaran K. Effect of obesity on airway inflammation: a cross-sectional analysis of body mass index and sputum cell counts. Clin Exp Allergy 2007; 37: $1049-54$

18. Sutherland TJ, Cowan JO, Young S, et al. The association between obesity and asthma: interactions between systemic and airway inflammation. Am J Respir Crit Care Med 2008; 178: 469-75.

19. van Veen IH, Ten Brinke A, Sterk PJ, Rabe KF, Be $\mathrm{EH}$. Airway inflammation in obese and nonobese patients with difficult-to-treat asthma. Allergy 2008; 63: 570-4.

20. Calixto M, Lintomen L, Schenka A, Saad MJ, Zanesco A, Antunes E. Obesity enhances eosinophilic inflammation in a murine model of allergic asthma. Br J Pharmacol 2010; 159: 617-25.

21. Hancox RJ, Milne BJ, Poulton R, et al. Sex differences in the relation between body mass index and asthma and atopy in a birth cohort. Am J Respir Crit Care Med 2005; 171: 440-5.

22. Schachter LM, Peat JK, Salome CM. Asthma and atopy in overweight children. Thorax 2003; 58: 1031-5.

23. Chen Y, Dales R, Jiang Y. The association between obesity and asthma is stronger in nonallergic than allergic adults. Chest 2006; 130: 890-5.

24. Jarvis D, Chinn S, Potts J, Burney P. Association of body mass index with respiratory symptoms and atopy: results from the European Community Respiratory Health Survey. Clin Exp Allergy 2002; 32: 831-7.

25. Loerbroks A, Apfelbacher CJ, Amelang M, Sturmer T. Obesity and adult asthma: potential effect modification by gender, but not by hay fever. Ann Epidemiol 2008; 18: 283-9.

26. Camargo CA, Jr., Sutherland ER, Bailey W, et al. Effect of increased body mass index on asthma risk, impairment and response to asthma controller therapy in African Americans. Curr Med Res Opin 26: 1629-35.

27. Sutherland ER, Lehman EB, Teodorescu M, Wechsler ME. Body mass index and phenotype in subjects with mild-to-moderate persistent asthma. J Allergy Clin Immunol 2009; 123: 1328-34 e1.

28. Camargo CA, Jr., Boulet LP, Sutherland ER, et al. Body mass index and response to asthma therapy: fluticasone propionate/salmeterol versus montelukast. $J$ Asthma 47: 76-82.

29. Aaron SD, Fergusson D, Dent R, Chen Y, Vandemheen KL, Dales RE. Effect of weight reduction on respiratory function and airway reactivity in obese women. Chest 2004; 125: 2046-52. 
30. Stenius-Aarniala B, Poussa T, Kvarnstrom J, Gronlund EL, Ylikahri M, Mustajoki P. Immediate and long term effects of weight reduction in obese people with asthma: randomised controlled study. BMJ 2000; 320 (7238): 827-32.

31. Eneli IU, Skybo T, Camargo CA, Jr. Weight loss and asthma: a systematic review. Thorax 2008; 63: 671-6.

32. Dixon JB, Chapman L, O'Brien P. Marked improvement in asthma after Lap-Band surgery for morbid obesity. Obesity Surg 1999; 9: 385-9.

33. Hakala K, Stenius-Aarniala B, Sovijarvi A. Effects of weight loss on peak flow variability, airways obstruction, and lung volumes in obese patients with asthma. Chest 2000; 118: 1315-21.

34. Nguyen NT, Hinojosa MW, Smith BR, Gray J, Varela E. Improvement of restrictive and obstructive pulmonary mechanics following laparoscopic bariatric surgery. Surg Endosc 2009; 23: 808-12.

35. Weiss ST. Obesity: insight into the origins of asthma. Nature Immunology 2005; 6: 537-9.

36. Tantisira KG, Weiss ST. Complex interactions in complex traits: obesity and asthma. Thorax 2001; $56 \mathrm{Suppl}$ 2: ii64-73.

37. Hallstrand TS, Fischer ME, Wurfel MM, Afari N, Buchwald D, Goldberg J. Genetic pleiotropy between asthma and obesity in a community-based sample of twins. J Allergy Clin Immunol 2005; 116: 1235-41.

38. Kiljander TO, Harding SM, Field SK, et al. Effects of esomeprazole $40 \mathrm{mg}$ twice daily on asthma: a randomized placebo-controlled trial. Am J Respir Crit Care Med 2006; 173: 1091-7.

39. Julien JY, Martin JG, Ernst P, et al. Prevalence of obstructive sleep apnea-hypopnea in severe versus moderate asthma. J Allergy Clin Immunol 2009; 124: 371-6.

40. Gunnbjornsdottir MI, Omenaas E, Gislason T, et al. Obesity and nocturnal gastro-oesophageal reflux are related to onset of asthma and respiratory symptoms. Eur Respir J 2004; 24: 116-21.

41. Beuther DA, Weiss ST, Sutherland ER. Obesity and asthma. Am J Respir Crit Care Med 2006; 174: 112-9.

42. Salome CM, King GG, Berend N. Physiology of obesity and effects on lung function. J Appl Physiol 2010; 108: 206-11.

43. Beuther DA. Obesity and asthma. Clinic Chest Med 2009; 30: 479-88, viii.

44. Weiner P, Waizman J, Weiner M, Rabner M, Magadle $\mathrm{R}$, Zamir D. Influence of excessive weight loss after gastroplasty for morbid obesity on respiratory muscle performance. Thorax 1998; 53: 39-42.

45. Bergeron C, Boulet LP, Hamid Q. Obesity, allergy and immunology. J Allergy Clin Immunol 2005; 115: 1102-4.

46. Salome CM, Munoz PA, Berend N, Thorpe CW, Schachter LM, King GG. Effect of obesity on breathlessness and airway responsiveness to methacholine in nonasthmatic subjects. Intern J Obesity 2008; 32: 502-9.

47. Deesomchok A, Fisher T, Webb KA, et al. Effects of Obesity on Perceptual and Mechanical Responses to Bronchoconstriction in Asthma. Am J Respir Crit Care Med 2010; 181: 125-33.

48. Ronti T, Lupattelli G, Mannarino E. The endocrine function of adipose tissue: an update. Clin Endocrinol 2006; 64: 355-65.

49. Hotamisligil GS, Shargill NS, Spiegelman BM. Adipose expression of tumor necrosis factor-alpha: direct role in obesity-linked insulin resistance. Science (New York, NY) 1993; 259 (5091): 87-91.

50. Lord GM, Matarese G, Howard JK, Baker RJ, Bloom SR, Lechler RI. Leptin modulates the T-cell immune response and reverses starvation-induced immunosuppression. Nature 1998; 394 (6696): 897-901.

51. Considine RV, Sinha MK, Heiman ML, et al. Serum immunoreactive-leptin concentrations in normal- weight and obese humans. New Emgl J Med 1996; 334: 292-5.

52. Couillard C, Mauriege P, Imbeault P, et al. Hyperleptinemia is more closely associated with adipose cell hypertrophy than with adipose tissue hyperplasia. Int $J$ Obes Relat Metab Disord 2000; 24: 782-8.

53. Guler N, Kirerleri E, Ones U, Tamay Z, Salmayenli $\mathrm{N}$, Darendeliler F. Leptin: does it have any role in childhood asthma? J Allergy Clin Immunol 2004; 114: 254-9.

54. Mai XM, Bottcher MF, Leijon I. Leptin and asthma in overweight children at 12 years of age. Pediatr Allergy Immunol 2004; 15: 523-30.

55. Bruun JM, Lihn AS, Verdich C, et al. Regulation of adiponectin by adipose tissue-derived cytokines: in vivo and in vitro investigations in humans. Am J Physiol Endocrinol Metab 2003; 285: E527-33.

56. Engeli S, Feldpausch M, Gorzelniak K, et al. Association between adiponectin and mediators of inflammation in obese women. Diabetes 2003; 52: 942-7.

57. Kim KW, Shin YH, Lee KE, Kim ES, Sohn MH, Kim KE. Relationship between adipokines and manifestations of childhood asthma. Pediatr Allergy Immunol 2008; 19: 535-40

58. Sutherland TJ, Sears MR, McLachlan CR, Poulton R, Hancox RJ. Leptin, adiponectin, and asthma: findings from a population-based cohort study. Ann Allergy Asthma Immunol 2009; 103: 101-7.

59. Sood A, Cui X, Qualls C, et al. Association between asthma and serum adiponectin concentration in women. Thorax 2008; 63: 877-82.

60. Jartti T, Saarikoski L, Jartti L, et al. Obesity, adipokines and asthma. Allergy 2009; 64: 770-7.

61. Xu H, Barnes GT, Yang Q, et al. Chronic inflammation in fat plays a crucial role in the development of obesity-related insulin resistance. J Clin Invest 2003; 112: 1821-30.

62. Weisberg SP, McCann D, Desai M, Rosenbaum M, Leibel RL, Ferrante AW, Jr. Obesity is associated with macrophage accumulation in adipose tissue. J Clin Invest 2003; 112: 1796-808.

63. Cottam DR, Schaefer PA, Shaftan GW, Velcu L, Angus LD. Effect of surgically-induced weight loss on leukocyte indicators of chronic inflammation in morbid obesity. Obes surg 2002; 12: 335-42.

64. Esposito K, Pontillo A, Di Palo C, et al. Effect of weight loss and lifestyle changes on vascular inflammatory markers in obese women: a randomized trial. JAMA 2003; 289: 1799-804.

65. Bastard JP, Jardel C, Bruckert E, et al. Elevated levels of interleukin 6 are reduced in serum and subcutaneous adipose tissue of obese women after weight loss. J Clin Endocrinol Metab 2000; 85: 3338-42.

66. Leone N, Courbon D, Thomas F, et al. Lung function impairment and metabolic syndrome: the critical role of abdominal obesity. Am J Respir Crit Care Med 2009; 179: 509-16.

67. Lee EJ, In KH, Ha ES, et al. Asthma-like symptoms are increased in the metabolic syndrome. J Asthma 2009; 46: 339-42.

68. Husemoen LL, Glumer C, Lau C, Pisinger C, Morch LS, Linneberg A. Association of obesity and insulin resistance with asthma and aeroallergen sensitization. $\mathrm{Al}$ lergy 2008; 63: 575-82.

69. Thuesen BH, Husemoen LL, Hersoug LG, Pisinger C, Linneberg A. Insulin resistance as a predictor of incident asthma-like symptoms in adults. Clin Exp Allergy 2009; 39: 700-7.

70. Shore SA, Williams ES, Zhu M. No effect of metformin on the innate airway hyperresponsiveness and increased responses to ozone observed in obese mice. $J$ Appl Physiol 2008; 105: 1127-33. 
71. Lang JE, Feng H, Lima JJ. Body mass index-percentile and diagnostic accuracy of childhood asthma. J Asthma 2009; 46: 291-9.

72. Aaron SD, Vandemheen KL, Boulet LP, et al. Overdiagnosis of asthma in obese and nonobese adults. Can Med Ass J 2008; 179: 1121-31

73. Pakhale S, Doucette S, Vandemheen K, et al. A comparison of obese and nonobese asthmatics: Exploring an asthma-obesity interaction. Chest 2010; 137: 1316-23.

74. Gorber SC, Tremblay M, Moher D, Gorber B. A com- parison of direct vs. self-report measures for assessing height, weight and body mass index: a systematic review. Obes Rev 2007; 8: 307-26.

75. Harik-Khan RI, Wise RA, Fleg JL. The effect of gender on the relationship between body fat distribution and lung function. J Clin Epidemiol 2001; 54: 399-406.

76. Steele RM, Finucane FM, Griffin SJ, Wareham NJ, Ekelund U. Obesity is associated with altered lung function independently of physical activity and fitness. Obesity 2009; 17: 578-84.

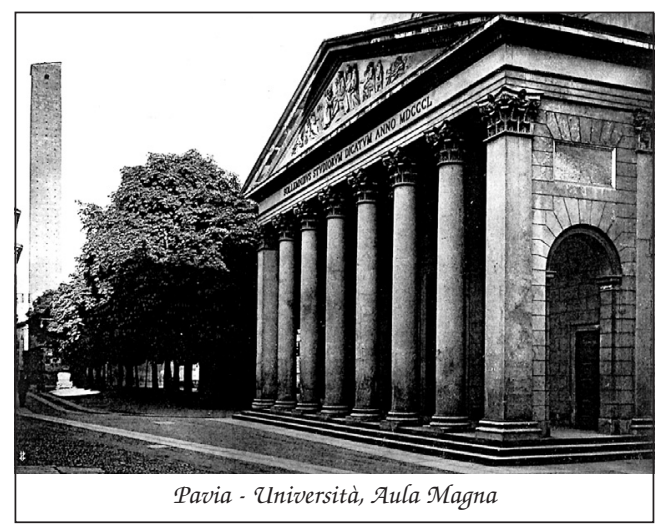

